\title{
Environmental DNA detection and quantification of invasive red-eared sliders, Trachemy scripta elegans, in ponds and the influence of water quality
}

\author{
Aozora Kakuda ${ }^{1}$, Hideyuki Doi ${ }^{\text {Corresp., }}{ }^{2}$, Rio Souma ${ }^{3}$, Mariko Nagano ${ }^{2}$, Toshifumi Minamoto ${ }^{4}$, Izumi Katano ${ }^{\text {Corresp. } 1}$ \\ ${ }^{1}$ Graduate School of Humanities and Sciences, Nara Women's University, Nara, Japan \\ 2 Graduate School of Simulation Studies, University of Hyogo, Kobe, Japan \\ 3 IDEA Consultants Inc., Yaizu, Japan \\ ${ }^{4}$ Graduate School of Human Development and Environment, Kobe University, Kobe, Japan \\ Corresponding Authors: Hideyuki Doi, Izumi Katano \\ Email address: hideyuki.doi@icloud.com, katano@cc.nara-wu.ac.jp
}

Environmental DNA (eDNA) is a powerful tool for monitoring the distribution of aquatic macro-organisms. However, environmental factors, including the water temperature and water quality, can affect the inhibition and/or degradation of eDNA, which complicates accurate estimations of eDNA concentrations and the detection of the presence/absence of species in natural habitats. Further very few eDNA studies have been conducted for reptiles, especially with respect to estimating their biomass and/or abundances. Here we examined the relationship between the visually-observed number of red-eared sliders (Trachemys scripta elegans) and eDNA concentrations across 100 ponds. Additionally, we evaluated the effect of water quality on red-eared slider eDNA concentration in these ponds. We found that there was a significant positive correlation between the observed number of red-eared sliders and the eDNA concentration in the ponds. On comparing various water quality indicators, including dissolved nitrogen, dissolved phosphorous, organic matter, and chlorophyll a (Chl. a), we found that only Chl. a had a negative correlation with the red-eared slider eDNA concentration, while we did not find any inhibition in the quantitative PCR. We conclude that concentrations of eDNA can potentially be used for estimating the abundance of the red-eared slider. Additionally, Chl. a might indirectly influence the degradation of eDNA through the microorganisms bonded to the phytoplankton in the ponds, as microbial activity is thought to decrease eDNA persistence. 
1 For PeerJ,

\section{Environmental DNA detection and quantification of invasive}

3 red-eared sliders, Trachemy scripta elegans, in ponds and the

\section{4 influence of water quality}

7 Aozora Kakuda ${ }^{1}$, Hideyuki Doi ${ }^{2 *}$, Rio Souma ${ }^{3}, \mathrm{Marik} \mathrm{Nagano}^{2}$, Toshifumi Minamoto ${ }^{4}$, and

$8 \quad$ Izumi Katano $^{1 *}$

${ }^{1}$ Graduate School of Humanities and Sciences, Nara Women's University, Kitanoya-nishimachi,

11 Nara 630-8506, Japan

$12{ }^{2}$ Graduate School of Simulation Studies, University of Hyogo, 7-1-28, Minatojimaminamimachi, Chuo-ku, Kobe, 650-0047, Japan

* Co-corresponding authors:

Izumi Katano, e-mail: katano@cc.nara-wu.ac.jp

Hideyuki Doi, e-mail: hideyuki.doi@icloud.com 
25 Abstract

26 Environmental DNA (eDNA) is a powerful tool for monitoring the distribution of aquatic macroorganisms. However, environmental factors, including the water temperature and water quality, can affect the inhibition and/or degradation of eDNA, which complicates accurate estimations of eDNA concentrations and the detection of the presence/absence of species in natural habitats. Further very few eDNA studies have been conducted for reptiles, especially with respect to estimating their biomass and/or abundances. Here we examined the relationship between the visually-observed number of red-eared sliders (Trachemys scripta elegans) and eDNA concentrations across 100 ponds. Additionally, we evaluated the effect of water quality on redeared slider eDNA concentration in these ponds. We found that there was a significant positive correlation between the observed number of red-eared sliders and the eDNA concentration in the ponds. On comparing various water quality indicators, including dissolved nitrogen, dissolved phosphorous, organic matter, and chlorophyll a (Chl. $a$ ), we found that only Chl. $a$ had a negative correlation with the red-eared slider eDNA concentration, while we did not find any inhibition in the quantitative PCR. We conclude that concentrations of eDNA can potentially be used for estimating the abundance of the red-eared slider. Additionally, Chl. a might indirectly

41 influence the degradation of eDNA through the microorganisms bonded to the phytoplankton in the ponds, as microbial activity is thought to decrease eDNA persistence. 


\section{Introduction}

Environmental DNA (eDNA) methods for monitoring the distribution of aquatic species

have recently been developed (Ficetola et al., 2008; Ree et al., 2014; Goldburg \& Strickler,

2015). The eDNA consists of DNA fragments released through the mucus, urine, gametes, or

feces of species in the environment. In 2008, Ficetola et al. (2008) first used the eDNA method

for a macro-organism, the American bullfrog (Rana catesbeiana), to detect their presence in

ponds using water samples. It is possible to analyze DNA fragments of target species from a few

liters or less of water (Ficetola et al., 2008; Ree et al., 2014; Goldberg \& Strickler, 2015; Denier

et al., 2017). As we just sample the water in the field, eDNA methods are non-invasive, take a

shorter time, and cost less compared with traditional monitoring methods, capture or visual

survey (Thomsen \& Willerslev, 2015).

The eDNA analysis has been applied to various aquatic taxa, for example, fish

(Minamoto et al., 2012; Thomsen et al., 2012a; Takahara et al., 2012, 2013; Eichmiller et al.,

2016a), amphibians (Ficetola et al., 2008; Pilliod et al., 2013; Fukumoto et al., 2015; Katano et

al., 2017), mollusks (Goldberg et al., 2013), crustaceans (Tréguier et al., 2014), insects

(Thomsen et al., 2012b; Doi et al., 2017b), trematodes (Huver et al., 2015; Hashizume et al.,

2017), and aquatic plants (Fujiwara et al., 2016). However, there are few studies for reptiles,

Lacoursière-Roussel et al., 2016). 

species, the red-eared slider (Trachemys scripta elegans). The red-eared slider is listed in the top 100 of the world's worst invasive species by the World Conservation Union IUCN (Global Invasive Species Database, http://www.issg.org/database). In Japan, red-eared sliders were imported from USA as a pet in the 1950s, and since then it has been released into the local natural habitats

(Oi et al., 2011). This species is an omnivore and it has gained some attention as they affect indigenous animals (Lever, 2003). In 2013, The Nature Conservation Society of Japan (NACS-J) conducted a visual survey in 41 of the 47 prefectures in Japan $(\mathrm{N}=4,146)$, and reported that $64 \%$ of the turtle individuals observed were identified as red-eared sliders (NACS-J, 2013). Red-eared sliders disrupt pond ecosystems and have expanded their distribution into numerous ponds in Japan (Taniguchi et al., 2017). It is important to rapidly elucidate the distribution of invasive species to conserve the ecosystems in which they reside (Pyšek \& Richardson, 2010); thus, methods to easily detect red-eared sliders, which are one of the common invasive species in Japan, should be developed. However, the effective sampling methods for turtles depends on the target species. Sterrett et al. (2010), suggested that we might underestimate the abundance of red-eared sliders by using visual observations. Thus, eDNA methods would be a useful tool to replace visual observations for evaluating the turtle distribution. freshwater systems suggest that a number of environmental factors affect the probability of eDNA detection; for example, the water temperature and water quality, including the $\mathrm{pH}$, suspended solid (SS), total phosphorous (TP), total nitrogen (TN), biological oxygen demand 
85 (BOD), and chlorophyll a (Chl. a) (e.g., Barnes et al., 2014; Strickler et al., 2014; Eichmiller et

86 al., 2016b; Song et al., 2017). These factors can lead to false negative detections, which prevents

87 the accurate evaluation of eDNA concentrations and detection of the distribution/quantification

88 of a species. To improve the eDNA evaluation of distribution and biomass/abundance in natural

89 habitats, we should understand the relationship between eDNA detection rate/concentration and

90 these environmental factors.

Two main environmental factors that negatively influence eDNA detection rate are

'inhibition' and 'degradation'. In fact, humic acids are known to inhibit DNA polymerase in

PCR (Matheson et al., 2010), and therefore, it could directly impact on eDNA detection.

Mesocosm studies have found that a number of factors are important to decreasing the

et al., 2014; Strickler et al., 2014). Although these studies are based on laboratory experiments, in rivers, eDNA detection rate has been known to decrease with increasing Chl. $a$, but increase with increasing water temperature and $\mathrm{pH}$ (Song et al., 2017). Because the effect of Chl. $a$ was different in laboratory vs. in situ experiments, more evidence is needed to understand the effects of water quality on eDNA degradation, however, there are few studies on this conducted in the 102 field.

We hypothesized that eDNA would be a suitable method to determine the distribution of red-eared sliders and that water quality would influence/inhibit eDNA measurement by quantitative real-time PCR (qPCR). In this study, our aim was to compare the eDNA 
106

107

108

109

110

111

112

113

114

115

116

117

118

119

120

121

122

123

124

125

126

concentrations of the target species, by using qPCR paired with visual observations of the turtles.

Specifically, we evaluated the species abundance with the measurements of eDNA

concentrations in 100 study ponds. From the eDNA concentration and water quality data, we examined the relationships between the water quality and eDNA concentrations of the red-eared slider, to consider the water quality effects that influence eDNA degradation and PCR inhibition in the ponds.

\section{Materials \& Methods}

\section{Study site}

We conducted the field survey in 100 ponds that were located in Himeji, Japan $\left(34^{\circ} 47^{\prime}-34^{\circ} 54^{\prime}\right.$

N, 134 $35^{\prime}-134^{\circ} 45^{\prime}$ E, Fig. 1) between July 21 and November 16, 2016. We randomly selected ponds located in each area category, comprising city, rural, and mountain areas (see Table 1A, B, Figure S1 in Supplemental Electronic Materials (SEM)). There are few ponds in the southern (city area) and northern areas (mountain) because the distribution of the ponds is biased. We conducted statistical analysis among the three area categories and eDNA concentration, but did not find remarkable patterns of eDNA concentration and detection among the pond locations. The field survey and pond sampling was permitted by the land owners, if needed.

Field survey and sampling

We recorded the presence/absence and number of red-eared sliders, based on visual observations 
127 from the shore line for three minutes by an expert (A. Kakuda). We performed surveys during

128 the daytime (1000-1300 h) each day, except for rainy days and one day after rain. From a point

129 within each pond, $500 \mathrm{~mL}$ of surface water was collected for eDNA and SS analysis, and a

130 further $100 \mathrm{~mL}$ of surface water was collected for Chl. $a$ and water quality analysis. In this study,

131 we conducted a field survey to compare the convenience of the eDNA method with visual

132 surveys; thus, we decided to increase the number of sampling ponds rather than increase the

133 replications at each pond. We selected a water sampling point in the middle section of the ponds,

134 far from the water outflows/inflows. We directly sampled the eDNA using a bleached bottle and

135 added $0.5 \mathrm{~mL}$ of benzalkonium chloride (BAC) to avoid a reduction of the eDNA concentration

136 in the samples (Yamanaka et al., 2016). Samples were stored in a cooler box with a 'cooler

137 blank'. The 'cooler blank' contained $500 \mathrm{~mL}$ of DNA-free water, which we brought to the field,

138 and it was treated identically to the other water samples, except that it was not opened at the field

139 sites.

Water preparation

142 Within six hours after water sampling, the samples were filtered onto a GF/F glass filter (47 mm

143 diameter and $0.7 \mu \mathrm{m}$ pore size, GE Healthcare Japan, Tokyo, Japan). We used separate filters for

144 the eDNA, SS (from $500 \mathrm{~mL}$ water), and Chl. $a$ (from $100 \mathrm{~mL}$ water) analysis. The filter was

145 then wrapped in commercial aluminum foil and stored at $-20^{\circ} \mathrm{C}$ until eDNA extraction, or SS/

146 Chl. a measurement. For eDNA samples, the 'cooler blank' and a 'filter blank' consisting of

147 DNA-free distilled water were filtered in the same way as the samples. To avoid contamination, 
148

149

150

151

152

153

154

155

156

157

158

159

160

161

162

each piece of equipment that was used in the water sampling or filtration was soaked in a $10 \%$ commercial bleach solution (approximately $0.6 \%$ sodium hypochlorite) and rinsed using DNAfree distilled water prior to reuse. The $80 \mathrm{~mL}$ of the filtrated samples were stored at $-20{ }^{\circ} \mathrm{C}$ until further water quality analyses. We lost some of the samples for water quality measurements (see the missing values of Table S1A, B in SEM).

\section{DNA extraction from the filters}

The eDNA was extracted from each filter using a DNeasy Blood \& Tissue Kit (Qiagen, Hilden, Germany) based on the method described by Uchii et al. 2016. Each filtrate was soaked in 400 $\mu \mathrm{L}$ of buffer AL and $40 \mu \mathrm{L}$ of protease K in a Salivette tube (Sarstedt, Nümbrecht, Germany) and incubated at $56{ }^{\circ} \mathrm{C}$ for $30 \mathrm{~min}$. After centrifugation at $5000 \mathrm{~g}$ for $5 \mathrm{~min}, 220 \mu \mathrm{L}$ of TE buffer ( $\mathrm{pH}$ 8.0) was added to each filter, and the tubes were centrifuged again in the same way after being kept for a minute. The $200 \mu \mathrm{L}$ of buffer AL and $600 \mu \mathrm{L}$ of $100 \% \mathrm{EtOH}$ were then added to each filtrate and mixed by pipetting. The mixture was applied to a DNeasy Mini spin column and prepared according to the manufacture's manual. The sample solution (100 $\mu \mathrm{L}$ of buffer AE) was stored in a $1.5 \mathrm{~mL}$ microtube at $-20{ }^{\circ} \mathrm{C}$ until $\mathrm{qPCR}$ analysis.

Quantitative real-time PCR ( $q P C R)$

The eDNA was measured with four PCR replicates using a PikoReal Real-Time PCR System (Thermo Scientific, Waltham, MA, USA). To detect and quantify the DNA of the red-eared slider using qPCR, the mitochondrial cytochrome b gene fragments were amplified and 
169

170

171

172

173

174

175

176

quantified with the following primers and probe: Tse-Kako-A-F (5'-

CCTCCAACATCTCTGCTTGA -3'), Tse-Kako-A-R (5'- ATTGTACGTCTCGGGTGATG -3'), and Tse-Kako-A-MGB-P (5'-FAM- CGGAATTTTCTTGGCTATAC -MGB-3'). We used the consensus sequence of Trachemy scripta elegans with the following accession numbers:

FJ770617, FR717131, EU787024, AF207750, and HQ442420 in NCBI

(http://www.ncbi.nlm.nih.gov/). From the consensus sequence, we artificially synthesized a standard gene, which included the amplicon region and 20 bases each of the upper and lower sequences $\left(5^{\prime}-\right.$

ATTCATTGATCTACCAAGCCCCTCCAACATCTCTGCTTGATGGAACTTTGGATCCTTA TTAGGTACTTGCCTAATCCTACAAATCCTTACCGGAATTTTCTTGGCTATACACTACT CCCCAGACATTTCACTAGCATTCTCATCAGTAGCCCACATCACCCGAGACGTACAAT ACGGATGACTTATTCGTAAT-3'). The specificity of the probe and primers was confirmed by Primer-BLAST and testing on Japanese turtles (Mauremys japonica, Mauremys reevesii, and Pelodiscus sinensis). Each TaqMan reaction contained $900 \mathrm{nM}$ of each primer, $125 \mathrm{nM}$ of TaqMan probe, $5 \mu \mathrm{L}$ qPCR master mix (TaqMan Environmental Master Mix 2.0, Thermo Scientific, Waltham, MA, USA), $0.2 \mu \mathrm{L}$ AmpErase ${ }^{\circledR}$ Uracil N-Glycosylase (UNG, Thermo Scientific, Waltham, MA, USA), and $2 \mu \mathrm{L}$ of the DNA solution. The total volume of each reaction mixture was $10 \mu \mathrm{L}$ and we performed four replicates for PCR. The PCR conditions were as follows: $2 \mathrm{~min}$ at $50^{\circ} \mathrm{C}, 10 \mathrm{~min}$ at $95^{\circ} \mathrm{C}$, and 55 cycles of $15 \mathrm{~s}$ at $95^{\circ} \mathrm{C}$ and $60 \mathrm{~s}$ at $60{ }^{\circ} \mathrm{C}$. These cycles are based on various previously described methods (Thomsen et al. 2012a; Tréguier et al. 2014; Katano et al. 2017; Doi et al. 2017). The qPCR results were analyzed using PikoReal 
190 software ver. 2.2.248.601 (Thermo Fisher Scientific, Waltham, MA, USA), and the standard

191 curves were also automatically estimated by this software. The $\mathrm{R}^{2}$ values of the standard curves

192 ranged from 0.960 to 0.989 , and PCR efficiency ranged from 73.09 to $118.56 \%$. For the $R^{2}$

193 values, there is a possibility that we measured the eDNA in the qPCR system with order-level

194 differences because of the high variance in eDNA concentration, from 0.21 to 48016.44

195 (copies/L). We defined the limit of detection (LOD) for red-eared slider DNA as one copy per

196 reaction based on a qPCR assay of the four replicates. Each real-time PCR assay included four

197 no template controls (NTCs) and we also measured the cooler and filter blanks with four

198 replicates. We used the average value of the four replicates for each eDNA concentration. All of

199 the above qPCR procedures were based on the MIQE checklist for qPCR (Bustin et al., 2009).

200 We performed the PCR set up and real-time PCR in two separate rooms to avoid contamination.

PCR inhibition test

203

204

205

206

207

208

209

210

We compared the $\mathrm{Ct}$ shift between the samples and controls with the same number of known target DNA copies, based on the method by Doi et al. (2017b), to confirm the degree of PCR inhibition. $\mathrm{Ct}$ is defined as the number of cycles required for enough amplified PCR product to accumulate that it surpasses a threshold recognized by the real-time PCR instrumentation. The Ct is inversely related to the starting quantity of the target DNA in a reaction and is used to calculate this quantity. The presence of PCR inhibitors will shift (delay) the $\mathrm{Ct}$ for a given quantity of the template DNA. To confirm the effects of water quality factors on eDNA inhibition, we did not use a PCR inhibition removal kit (e.g., OneStep PCR Inhibitor Removal 
211 Kit, Zymo Research) for the qPCR preparation. To test for PCR inhibition in the DNA samples,

$2121 \mu \mathrm{L}$ of plasmid including the cytochrome $\mathrm{b}$ gene from Trachurus japonicus $\left(1.5 \times 10^{4}\right.$ copies $)$,

213 which is a marine fish that does not inhabit the sampled ponds, was added to the PCR tempelate

214 with $1 \mu \mathrm{L}$ of DNA-free distilled water. We used the primer and probe set that was reported by

215 Yamamoto et al. 2016: forward primer: 5'-CAGATATCGCAACCGCCTTT-3'; reverse primer:

216 5'-CCGATGTGAAGGTAAATGCAAA-3'; and probe: 5'-FAM-

217 TATGCACGCCAACGGCGCCT-TAMRA-3'. The PCR conditions were the same as above.

218 Each real-time PCR assay included three no template controls. We used the average value of the

219 replicates for each $\mathrm{Ct}$ value. $\Delta \mathrm{Ct} \geq 3$ cycles were considered to be evidence of inhibition

220 (Hartman et al., 2005).

Water quality analysis

We measured phosphate $\left(\mathrm{PO}_{4}-\mathrm{P}\right)$, nitrate $\left(\mathrm{NO}_{3}-\mathrm{N}\right)$, total phosphorus $(\mathrm{TP})$, total nitrogen $(\mathrm{TN})$,

dissolved organic matter (DOM), and total organic matter (TOM) from the filtrate, according to the methods of Saijo \& Mitamura (1995), using a spectrophotometer (HITACHI U-5100, Hitachi, Tokyo, Japan). The absorbance of DOM was read at $254 \mathrm{~nm}$, using samples not in an

227 autoclave.

\section{SS measurement}

230 We used the GF/F glass filter, which had been burned and dried before the weight was measured 231 by electric balance (Sartorius CPA2252), prior to the SS analysis. The filtrate was dried in the 60 
$232{ }^{\circ} \mathrm{C}$ automatic oven (Yamato DX402, Yamato, Japan) over $12 \mathrm{~h}$ before the weight was measured.

233 After that, we burned the dried filter at $450{ }^{\circ} \mathrm{C}$ for $2 \mathrm{~h}$ using an electric muffle furnace (Yamato

234 FO410), then measured the weight again in the same way. The SS content was calculated as

235 follows; $\left(450^{\circ} \mathrm{C}\right.$ burned weight $)-\left(60^{\circ} \mathrm{C}\right.$ dried weight $)$.

236

237

Chl. a measurement

238 We extracted the Chl. $a$ of the filter by immersing it in $99.5 \%$ ethanol over $12 \mathrm{~h}$. The extracts

239 were measured at $630,645,663$, and $750 \mathrm{~nm}$ absorbances by the spectrophotometer (HITACHI

$240 \mathrm{U}-5100)$. The Chl. $a$ concentration was determined according to the following equation

241 (UNECSO 1969):

242

243

Chl. $a(\mathrm{mg} \mathrm{L}-1)=\{(11.64 \times \mathrm{E} 663-2.16 \times \mathrm{E} 645+0.1 \times \mathrm{E} 630) \times \mathrm{k}\} / \mathrm{V}$

244

245

where, k: ethanol for extraction (mL); E663, E645, and E630: each absorbance at 663, 645, 630

$\mathrm{nm}$, excluding the absorbance at $750 \mathrm{~nm}$; and V: water samples (L).

\section{Statistical analysis}

249 We used a linear model (LM) to evaluate the relationship between the red-eared slider eDNA

250 concentration and the number of red-eared sliders observed visually. For the eDNA

251 concentration and the number of red-eared sliders reported by visual observation, we used the

252 data of the sites where red-eared sliders were detected, regardless of the eDNA detection (11 
253

254

255

256

257

258

259

260

261

262

263

264

265

266

267

268

269

270

271

272

273

ponds in which red-eared sliders were detected by both methods and 10 ponds in which they were detected only by visual observation; $\mathrm{N}=21$; Table $\mathrm{S} 1 \mathrm{~A}, \mathrm{~B})$. In addition, we used a multiple linear regression to evaluate the relationship between the eDNA concentration and the following environmental factors: Chl. $a$, SS, $\mathrm{PO}_{4}-\mathrm{P}, \mathrm{NO}_{3}-\mathrm{N}, \mathrm{TP}, \mathrm{TN}, \mathrm{DOM}, \mathrm{TOM}$, and estimated number of red-eared sliders (animals $/ \mathrm{km}^{2}$; from the result of eDNA concentration and the number of redeared sliders observed visually). We used the data of all sites in which eDNA was detected (11 ponds in which red-eared sliders were detected by both methods and nine ponds in which they were detected by only eDNA, $\mathrm{N}=20$, Table $\mathrm{S} 1 \mathrm{~A}, \mathrm{~B})$. Prior to the multiple linear regression, we used a variance inflation factor (VIF) to check the collinearity of the factors. The maximum VIF was 59.685 , indicating that co-linearity among the factors would influence the results of the multiple linear regression. Thus, we removed the factors with a VIF $>5$ to reduce the collinearity effect on the multiple linear regression, resulting in the Chl. $a$, TP, and number of red-eared sliders remaining in the final linear model (LM) analysis. All statistical analysis and graphics were conducted in R ver. 3.4.1 (R Core Team, 2018) with the "ggplot2" and "car" packages.

Results

\section{The relationships between eDNA measurements and visual observations}

Of the 100 surveyed ponds, we detected red-eared sliders in 30 ponds: they were detected in 11 ponds by both visual and eDNA surveys, 10 ponds by only visual survey, and 9 ponds by only the eDNA survey (Table 1A, B). All successful amplifications were considered to be red-eared 
274 sliders, because the probe and primers were confirmed to detect only red-eared sliders by Primer-

275 BLAST and were tested by real-time PCR using DNA extracted from Japanese turtles

276 (Mauremys japonica, Mauremys reevesii, and Pelodiscus sinensis) living in the same region.

277 There was a significant positive correlation between the eDNA concentrations in all ponds in

278 which eDNA was detected and the number of red-eared sliders identified by visual observations

$279\left(\mathrm{LM}, R^{2}=0.48, p<0.001, \mathrm{~N}=20\right.$, Figure 2$)$.

280 The $\Delta \mathrm{Ct}$ values in 99 of the 100 ponds, except pond No. 33, were lower than $3(0.27 \pm 0.22$,

281 mean $\pm \mathrm{SD}$ ), which means that they were lower than the inhibition criteria (Hartman et al.,

282 2005). Thus, PCR inhibition was not significant for all samples, but pond No. 33 showed no

283 amplification in the PCR inhibition test. We did not detect any amplifications in the negative

284 controls and equipment blanks, including the cooler and filter blanks.

The relationship between eDNA concentration and water quality

287 The results of the water quality analysis are shown in Table S1A, B of the SEM [Chl. $a$ : $0.04 \pm$

$0.10 \mu \mathrm{g} \mathrm{L}{ }^{-1}, \mathrm{SS}: 35.0 \pm 44.34 \mu \mathrm{g} \mathrm{L}^{-1}, \mathrm{PO}_{4}-\mathrm{P}: 0.78 \pm 0.87 \mu \mathrm{mol} \mathrm{L}^{-1}, \mathrm{NO}_{3}-\mathrm{N}: 38.93 \pm 18.25 \mu \mathrm{mol}$

$\mathrm{L}^{-1}$, TP: $1.00 \pm 0.99 \mu \mathrm{mol} \mathrm{L}-1, \mathrm{TN}: 29.53 \pm 30.77 \mu \mathrm{mol} \mathrm{L}-1, \mathrm{DOM}: 0.07 \pm 0.04(\mathrm{abs}=254 \mathrm{~nm})$, and TOM: $0.00 \pm 0.01(\mathrm{abs}=254 \mathrm{~nm})$, mean $\pm 1 \mathrm{SD}]$. The VIFs of the LM for each factor are shown in Table S2 in the SEM, of which the VIFs of the Chl. $a$ (4.391), TP (1.870), and estimated number of red-eared sliders (1.801) were lower than 5. The LM, without the factors and with a VIF of $>5$, showed that Chl. $a$ was negatively related with the eDNA concentration (LM, $\mathrm{p}<0.001$, Table 2, Table 3), while there was no significant relationship between the eDNA 
295

296

297

298

299

300

301

302

303

304

305

306

307

308

309

310

311

312

313

314

315

concentration and other factors (Fig. 3, Table S1A, B).

\section{Discussion}

We detected the eDNA of the red-eared slider in the surface water samples of the ponds. In this study, we designed the red-eared slider-specific primers and probe and showed that we can use them to detect the red-eared sliders in field samples. The red-eared slider is a common invasive species in Japan, but we found them in only a few sites. This is probably because we randomly selected the study ponds from each region, including less invasive sites in the mountain area. When comparing with the visual observations, we detected the red-eared slider by both the eDNA and visual surveys in 11 ponds. In the nine ponds where only eDNA detected turtles, we suspect that turtles were too rare to be observed by visual observation. In addition, eDNA methods have often been cited to detect rare or cryptic species (Barnes \& Turner, 2016). Our results in nine ponds support this phenomenon as the turtles were detected not by visual observation, but by eDNA. While, in the ten ponds detected by only visual observation, we sampled the eDNA at one point per pond as per the survey design. This result suggests that it was necessary to sample at several points at each study site, to decrease the false-negative eDNA detections (e.g., Tréguier et al., 2014; Thomsen et al., 2012a). It would be necessary to compare eDNA sampling at several points at each study site with other surveys in future studies. In summary, we can detect red-eared sliders using eDNA for two thirds of the total detections, by sampling only $500 \mathrm{~mL}$ of water at a point in the pond. However, we concluded that it might be appropriate to use both a visual survey and eDNA analysis for red-eared sliders, as eDNA 
316

produced false-negative detections when red-eared sliders were present.

We also found a significant positive correlation between the eDNA concentration and number of red-eared sliders detected by visual observation. Others, such as Takahara et al. (2012) have found positive correlations between eDNA concentrations and the biomass using both aquaria and outdoor experiments. The field tests for the relationship between eDNA concentration and biomass of amphibians and fish also support the positive correlation (e.g., Pilliod et al., 2013; Doi et al., 2017). Although few studies examining the effects of biomass or number of individuals on eDNA have used reptiles, Lacoursière-Roussel et al. (2016) found eDNA detection rate was highly correlated to the relative abundance of wood turtles. In our study, likewise, a positive relationship between the eDNA concentration and the abundance of visual detections was observed. Thus, we can possibly use the eDNA concentration to estimate the number of red-eared sliders, especially for the ponds with a high species abundance. From the relationships between water quality and eDNA concentration, Chl. $a$ seemed to influence the degradation of eDNA. One of our hypotheses was that water quality would influence/inhibit qPCR for eDNA detection, however, we could not find any inhibition of PCR by inhibition tests, except for a single pond (No. 33). Only pond No. 33 could be inhibited, because it showed no amplification of DNA. It is considered that one of the inhibitors of the PCR for pond No. 33 was humic acid from the decomposition of leaves, which is known to inhibit PCR detection (Opel et al. 2009), because it was surrounded by forest and the water color was black (Figure S2 in SEM). Thus, Chl. $a$ might not be directly related to PCR inhibition; however, it might have an influence with respect to decreasing the eDNA concentration in the water 
337 through DNA degradation. For the other water quality characteristics in our study, Eichmiller et 338 al. (2016b) measured the effects of Chl. a, TN, TP, and SS on the decay rate of carp eDNA in

339 laboratory experiments, however, these variables were not significantly correlated with the 340 eDNA decay rate (Eichmiller et al., 2016b). This result of non-correlations with TN, TP, and SS 341 to eDNA degradation was the same as our results, however, we showed the negative relationship 342 with Chl. $a$ and eDNA. Our result that only Chl. $a$ had a significant effect, might suggest that Chl. $a$ influences the degradation of eDNA in the surface water of ponds. However, this phenomenon seems to be in debate. For example, the eDNA decay rate has a negative relationship with Chl. $a$ in a mesocosm experiment for goldfish (Barnes et al., 2014), i.e., the eDNA degradation was less in the higher Chl. $a$. On the other hand, the eDNA detection rate has a negative relationship with Chl. $a$ in a field survey for silver carp (Song et al., 2017). In our study, the eDNA concentrations have a negative relationship with Chl. $a$, which supports the results of Song et al. 2017. As abiotic environmental factors indirectly influence the increase of microbial activities, eDNA may be decomposed by microorganisms (Barnes et al., 2014). Thus, the eDNA degradation by microorganisms bonded to phytoplankton, for example, indirectly increases microbial activities by providing basal resources (Lennon, 2007), although we did not directly evaluate the microbial activity. Further discussion on the "Chl. $a$ hypothesis" on eDNA degradation is required for understanding the mechanisms of eDNA degradation and for developing eDNA methods, especially for eDNA surveys in highly-productive water bodies. In this study, we can provide the hypothesis from the field data, but further field and laboratory experiments controlling the DNA 
concentration and water conditions, including the water quality and planktonic community, are required for understanding the mechanisms. In addition, we detected eDNA in only 20 ponds (11 ponds by both eDNA and visual observation and 9 ponds by only eDNA) by a single sampling from each pond. In future field studies, more replications would be needed.

\section{Conclusion}

In conclusion, we detected red-eared sliders using eDNA at a similar performance to that using visual observations, and evaluated the abundance using the eDNA concentration obtained from a single sampling point at each pond. In future field studies, more replications at each sites would be needed, as other studies (e.g. Barnes \& Turner, 2016) reported, which suggested that multiple water sampling points at a pond would increase the ability to evaluate the distribution and abundance by eDNA. Likewise, to prevent the spread of red-eared sliders, further developments of the eDNA method to easily detect them will be necessary in the future. We also provide the "Chl. $a$ hypothesis" for eDNA degradation for comparing the water quality of the ponds. For eDNA surveys, we should pay attention to the potential for false-negative detections, probably because of the state of primary production with reference to the Chl. $a$ concentration. Understanding the mechanisms in eDNA degradation would provide us with the tools for easy and accurate eDNA methods to evaluate the distribution of aquatic organisms.

\section{Acknowledgements}

We thank A. Sumi and D. Togaki for their helps on our sampling and experiments. 


\section{Funding Statement}

381 This study was supported by the Environment Research and Technology Development Fund (4382 1602) of the Ministry of the Environment, Japan and JST-CREST (JPMJCR13A2) and JSPS 383 KAKENHI (15K07233) for TM.

\section{References}

387 388

Barnes MA, Turner CR, Jerde CL, Renshaw MA, Chadderton WL, Lodge DM. 2014.

Environmental conditions influence eDNA persistence in aquatic systems. Environmental Science \& Technology 48:1819-1827. http://dx.doi.org/10.1021/es404734p.

Barnes MA, Turner CR. 2016. The ecology of environmental DNA and implications for conservation genetics. Cross Mark 17:1-17. https://doi.org/10.1007/s10592-015-0775-4.

Bustin SA, Benes V, Garson JA, Hellemans J, Huggett J, Kubista M, Mueller R, Nolan T, Pfaffl MW, Shipley GL, Vandesompele SJ, Wittwer CT. 2009. The MIQE guidelines: minimum information for publication of quantitative real-time PCR experiments. Clinical Chemistry 55:611-622. https://doi.org/10.1373/clinchem.2008.112797.

Davy CM, Kidd AG, Wilson CC. 2015. Development and validation of environmental DNA (eDNA) markers for detection of freshwater turtles. PLoS ONE 10:e0130965.

https://doi.org/10.1371/journal.pone.0130965.

De Souza LS, Godwin JC, Renshaw RA, Larson E. 2016. Environmental DNA (eDNA) 
400 detection probability is influenced by seasonal activity of organisms. PLoS ONE 11:1-15.

401 https://doi.org/10.1371/journal.pone.0165273.

402 Deiner K, Bik HM, Mächler E, Seymour M, Lacoursière-Roussel A, Altermatt F, Creer S, Bista

403 I, Lodge DM, Vere N, Pfrender ME, Bernatchez L. 2017. Environmental DNA metabarcoding:

404 Transforming how we survey animal and plant communities. Molecular Ecology 26:5872-5895.

405 https://doi.org/10.1111/mec.14350.

406 Doi H, Katano I, Sakata Y, Souma R, Kosuge T, Nagano M, Ikeda K, Yano K, Tojo K. 2017 b.

407 Detection of an endangered aquatic heteropteran using environmental DNA in a wetland

408 ecosystem. Royal Society Open Science 4:170568. https://doi.org/10.1098/rsos.170568.

409 Eichmiller JJ, Miller LM, Sorensen PW. 2016a. Optimizing techniques to capture and extract

410 environmental DNA for detection and quantification of fish. Molecular Ecology Resources

411 16:56-68. https://doi.org/10.1111/1755-0998.12421.

412 Eichmiller JJ, Best SE, Sorensen PW. 2016b. Effects of temperature and trophic state on

413 degradation of environmental DNA in lake water. Environmental Science \& Technology

414 50:1859-1867. http://doi.org/10.1021/acs.est.5b05672.

415 Ficetola GF, Miaud C, Pompanon F, Taberlet P. 2008. Species detection using environmental

416 DNA from water samples. Biology Letters 4:423-425. https://doi.org/10.1098/rsbl.2008.0118.

417 Fujiwara A, Matsuhashi S, Doi H, Yamamoto S, Minamoto T. 2016. Use of environmental DNA

418 to survey the distribution of an invasive submerged plant in ponds. Freshwater Science 35:748-

419 754. https://doi.org/10.1086/685882.

420 Fukumoto S, Ushimaru A, Minamoto T. 2015. A basin-scale application of environmental DNA 
421 assessment for rare endemic species and closely related exotic species in rivers: a case study of 422 giant salamanders in Japan. Journal of Applied Ecology 52:358-365.

423 https://doi.org/10.1111/1365-2664.12392.

424 Goldberg CS, Sepulveda A, Ray A, Baumgardt J, Waits LP. 2013. Environmental DNA as a new 425 method for early detection of New Zealand mudsnails (Potamopyrgus antipodarum). Freshwater 426 Science 32:792-800. https://doi.org/10.1899/13-046.1.

427 Hartman LJ, Coyne SR, Norwood DA. 2005. Development of a novel internal positive control 428 for TaqMan ${ }^{\circledR}$ based assays. Molecular and Cellular Probes 19:51-59.

429 https://doi.org/10.1016/j.mcp.2004.07.006.

430 Hashizume H, Sato M, Sato MO, Ikeda S, Yoonuan T, Sanguankiat S, Pongvongsa T, Moji K, 431 Minamoto T. 2017. Application of environmental DNA analysis for the detection of 432 Opisthorchis viverrini DNA in water samples. Acta Tropica 169:1-7.

433 https://doi.org/10.1016/j.actatropica.2017.01.008.

434 Huver JR, Koprivnikar J, Johnson PTJ, Whyard S. 2015. Development and application of an 435 eDNA method to detect and quantify a pathogenic parasite in aquatic ecosystems. Ecological 436 Applications 25(4):991-1002. https://doi.org/10.1890/14-1530.1.

437 Katano I, Harada K, Doi H, Souma R, Minamoto T. 2017. Environmental DNA method for 438 estimating salamander distribution in headwater streams, and a comparison of water sampling 439 methods. PLoS ONE 12(5):e0176541. https://doi.org/10.1371/journal.pone.0176541.

440 Lacoursière-Roussel A, Dubois Y, Normandeau E, Bernatchez L. 2016. Improving 441 herpetological surveys in eastern North America using the environmental DNA method. Genome 
442 59(11):991-1007. https://doi.org/10.1139/gen-2015-0218.

443 Lawson G. 2017. Development of eDNA techniques for the detection of Trachemys scripta in 444 aquatic samples and detection of prey items (Danio rerio) in Trachemys scripta fecal samples. 445 Faculty of California State University, Chico. http://hdl.handle.net/10211.3/200130.

446 Lennon JD. 2007. Diversity and metabolism of marine bacteria cultivated on dissolved DNA. 447 Applied and Environmental Microbiology 73:2799-2805. http://doi.org/10.1128/AEM.02674-06 448 Lever C. 2003 Naturalized reptiles and amphibians of the world. Oxford: Oxford University 449 Press. pp.17.

450 Mahon AR, Jerde CL, Galaska M, Bergner JL, Chadderton WL, Lodge DM, Hunter ME, Nico LG. 2013. Validation of eDNA surveillance sensitivity for detection of Asian carps in controlled and field experiments. PLOS ONE 8:e58316. https://doi.org/10.1371/journal.pone.0058316. environmental DNA from juvenile and adult fish. PLoS ONE 9:e114639.

Substances. The Open Enzyme Inhibition Journal 3:38-45. https://doi.org/10.1371/journal.pone.0114639.

Minamoto T, Yamanaka H, Takahara T, Honjo MN, Kawabata Z. 2012. Surveillance of fish species composition using environmental DNA. Limnology 13:193-197. https://doi.org/10.1007/s10201-011-0362-4.

461 Oi M, Araki J, Matsumoto J, Nogami S. 2011. Helminth fauna of a turtle species introduced in 462 Japan, the red-eared slider turtle (Trachemys scripta elegans). Veterinary Science 93:826-830. 
463

464

465

466

467

468

469

470

471

472

473

474

475

476

477

478

479

480

481

482

483

https://doi.org/10.1016/j.rvsc.2011.10.001.

Opel KL, Chung D, McCord BR. 2009. A study of PCR inhibition mechanisms using real time

PCR. Journal of Forensic Sciences 55:25-33. https://doi.org/10.1111/j.1556-4029.2009.01245.x.

Pilliod DS, Goldberg CS, Arkle RS, Waits LP. 2013. Estimating occupancy and abundance of stream amphibians using environmental DNA from filtered water samples. Canadian Journal of

Fisheries and Aquatic Sciences 70:1123-1130. https://doi.org/10.1139/cjfas-2013-0047.

Pyšek P, Richardson DM. 2010. Invasive Species, Environmental Change and Management, and Health. Annual Review of Environment and Resources 35:25-55.

https://doi.org/10.1146/annurev-environ-033009-095548.

Ramsay NF, Ng PKA, O’Riordan RM, Chou LM. 2007. The red-eared slider (Trachemys scripta elegans) in Asia: a review. In: Gherardi F, ed. Biological invaders in inland waters: Profiles, distribution, and threats. Dordrecht, The Netherlands: Springer Verlag. 161-174.

https://doi.org/10.1007/978-1-4020-6029-8_8.

R Core Team 2018 R: A language and environment for statistical computing, R Foundation for Statistical Computing, Vienna, Austria, https:/www.R-project.org/ (2018/05/15).

Rees HC, Maddison BC, Middleditch DJ, Patmore JR, Gough KC. 2014. REVIEW: The detection of aquatic animal species using environmental DNA-a review of eDNA as a survey tool in ecology. Journal of Applied Ecology 51:1450-1459. https://doi.org/10.1111/13652664.12306.

Saijo Y. Mitamura O. 1995. Shinpen Kosyo tyosaho method in limnological research (in Japanese). Kodansya, Tokyo. 
484 Song JW, Small MJ, Casman EA. 2017. Making sense of the noise: The effects of hydrology on 485 silver carp eDNA detection in the Chicago area waterway system. Science of the Total 486 Environment 605-606:713-720. https://doi.org/10.1016/j.scitotenv.2017.06.255.

487 Sterrett SC, Smith LL, Schweizer SH, Maerz JC. 2010. An assessment of two methods for 488 sampling river turtle assemblages. Herpetological Conservation and Biology 5:490-497.

Strickler KM, Fremier AK, Goldberg CS. 2014. Quantifying effects of UV-B, temperature, and 490 pH on eDNA degradation in aquatic microcosms. Biological Conservation 183:85-92. https://doi.org/10.1016/j.biocon.2014.11.038.

Takahara T, Minamoto T, Yamanaka H, Doi H, Kawabata Z. 2012. Estimation of fish biomass using environmental DNA. PLoS ONE 7:e35868. https://doi.org/10.1371/journal.pone.0035868. Takahara T, Minamoto T, Doi H. 2015. Effects of sample processing on the detection rate of environmental DNA from the Common Carp (Cyprinus carpio). Biological Conservation. 183:64-69. http://dx.doi.org/10.1016/j.biocon.2014.11.014.

Takahara T, Minamoto T, Doi H. 2013. Using environmental DNA to estimate the distribution of an invasive fish species in ponds. PLOS ONE 8:e56584. https://doi.org/10.1371/journal.pone.0056584.

500 Taniguchi, M, Lovich, JE, Mine, K, Ueno, S, Kamezaki, N. 2017. Unusual population attributes 501 of invasive red-eared slider turtles (Trachemys scripta elegans) in Japan: do they have a 502 performance advantage?. Aquatic Invasions. 12:1:97-108. https://doi.org/10.3391/ai.2017.12.1.10

The Nature Conservation Society of Japan (NACS-J). 2013. The research report of turtles in 
505

506 Thomsen PF, Kielgast J, Iversen LL, Wiuf C, Rasmussen M, Gilbert MTP. Orland L, Willerslev

Japan (in Japanese). The Nature Conservation Society of Japan document No. 53.

E. 2012a. Monitoring endangered freshwater biodiversity using environmental DNA. Molecular

Ecology 21:2565-2573. https://doi.org/10.1111/j.1365-294X.2011.05418.x.

Thomsen PF, Kielgast J, Iversen LL, Møller PR, Rasmussen M, Willerslev E. 2012b. Detection of a diverse marine fish fauna using environmental DNA from seawater samples. PLoS ONE 7:e41732. https://doi.org/10.1371/journal.pone.0041732.

Thomsen PF, Willerslev E. 2015. Environmental DNA-an emerging tool in conservation for monitoring past and present biodiversity. Biological Conservation 183:4-18.

https://doi.org/10.1016/j.biocon.2014.11.019.

Tréguier A, Paillisson JM, Dejean T, Valentini A, Schlaepfer MA, Roussel JM. 2014.

Environmental DNA surveillance for invertebrate species: advantages and technical limitations to detect invasive crayfish Procambarus clarkii in freshwater ponds. Journal of Applied Ecology 51:871-879. https://doi.org/10.1111/1365-2664.12262.

Uchii K, Doi H, Minamoto T. 2016. A novel environmental DNA approach to quantify the cryptic invasion of non-native genotypes, Molecular Ecology Resources 16:415-422. https://doi.org/10.1111/1755-0998.12460.

Yamamoto S, Minami K, Fukaya K, Takahashi K, Sawada H, Murakami H, Tsuji S, Hashizume H, Kubonaga S, Horiuchi T, Hongo M, Nishida J, Okugawa Y, Fujiwara A, Fukuda M, Hidaka S, Suzuki KW, Miya M, Araki H, Yamanaka H, Maruyama A, Miyashita K, Masuda R, Minamoto T, Kondoh M. 2016. Environmental DNA as a "Snapshot" of fish distribution: a case 
526 study of Japanese Jack Mackerel in Maizuru Bay, Sea of Japan. PLoS ONE 11:e0149786.

527 https://doi.org/10.1371/journal.pone.0149786.

528 Yamanaka H, Minamoto T, Matsuura J, Sakurai S, Tsuji S, Motozawa H, Hongo M, Sogo Y,

529 Kakimi N, Teramura I, Sugita M, BabYa M, Kondo A. 2016. A simple method for preserving

530 environmental DNA in water samples at ambient temperature by addition of cationic surfactant.

531 Limnology 18:233-241. https://doi.org/10.1007/s10201-016-0508-5.

532

533 
534 Figure legends

535

536

Figure 1 Study sites represented by red points.

Figure 2 Relationship between the visual observation number of red-eared sliders (Trachemys scripta elegans) per $\mathrm{km}^{2}$ and their eDNA concentrations in the ponds. The grey area represents the limits of the $95 \%$ confidence interval for the slope of the linear regression $\left(\mathrm{R}^{2}=0.48, \mathrm{p}<\right.$

$5410.001)$.

542

Figure 3 Relationships between each water-quality factor and the eDNA concentration of the red-eared slider in the ponds (A: Chl. $a$, B: SS, C: $\mathrm{PO}_{4}-\mathrm{P}, \mathrm{D}: \mathrm{NO}_{3}-\mathrm{N}, \mathrm{E}: \mathrm{TP}, \mathrm{F}: \mathrm{TN}, \mathrm{G}: \mathrm{DOM}, \mathrm{H}$ : TOM). The regression curve of Chl. $a$ was drawn by linear regression with $95 \%$ confidence

546 intervals for the slope $\left(\mathrm{R}^{2}=0.54, \mathrm{p}<0.001\right)$. 
548 Table 1A Sampling date, location, the detection of red-eared slider eDNA, and the number of

549 red-eared sliders visually observed in the study ponds. Observed by both eDNA and visual

550 observation is $\bigcirc$. Observed by only eDNA and by only visual observation are $\bigcirc$ and $\bullet$,

551 respectively.

552

553 Table 1B Continued.

554

555 Table 2 A) Linear regression slopes with a $\pm 95 \%$ confidence interval, $\mathrm{SE}, \mathrm{t}$ values, and $\mathrm{p}$ values

556 for the relationships between Chl. $a$, TP, estimated number of red-eared sliders (Turtles) and

557 eDNA concentrations in the ponds. Factors with a VIF $>5$ were removed.

559 Table 3 The table represents the $n, F$ value, $p$ value of the $F$ value, $R^{2}$, and adjusted $R^{2}$ for the 560 linear regression. 
Figure 1

Study sites represented by red points.

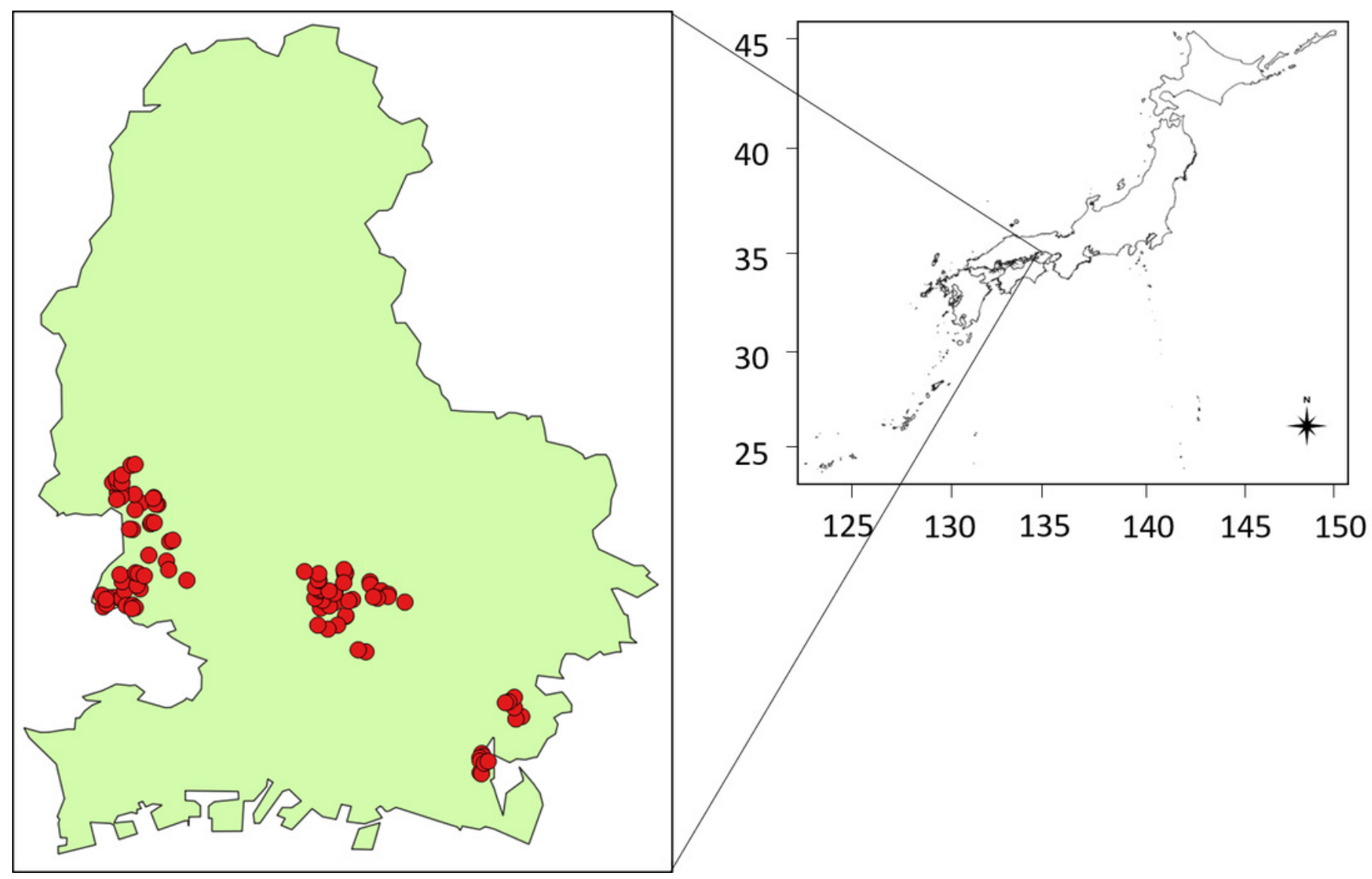


Figure 2

Relationship between the visual observation number of red-eared sliders (Trachemys scripta elegans) per $\mathrm{km}^{2}$ and their eDNA concentrations in the ponds.

The grey area represents the limits of the $95 \%$ confidence interval for the slope of the linear regression $\left(R^{2}=0.48, p<0.001\right)$. 


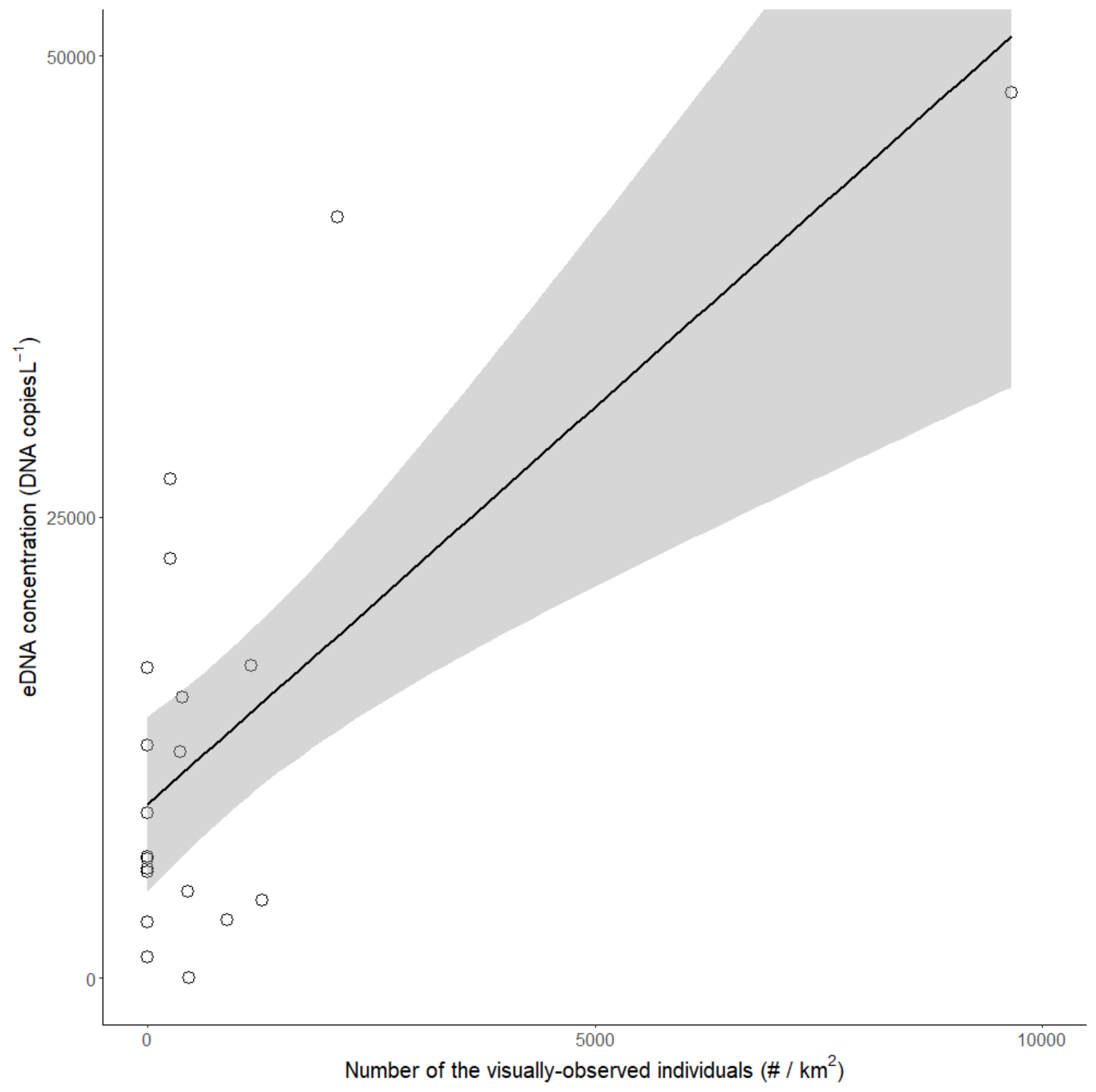


Figure 3

Relationships between each water-quality factor and the eDNA concentration of the redeared slider in the ponds (A: Chl. a, B: SS, C: $\mathrm{PO}_{4}-\mathrm{P}, \mathrm{D}: \mathrm{NO}_{3}-\mathrm{N}, \mathrm{E}: \mathrm{TP}, \mathrm{F}: \mathrm{TN}, \mathrm{G}: \mathrm{DOM}, \mathrm{H}$ : TOM).

The regression curve of Chl. a was drawn by linear regression with $95 \%$ confidence intervals for the slope $\left(R^{2}=0.54, p<0.001\right)$. 

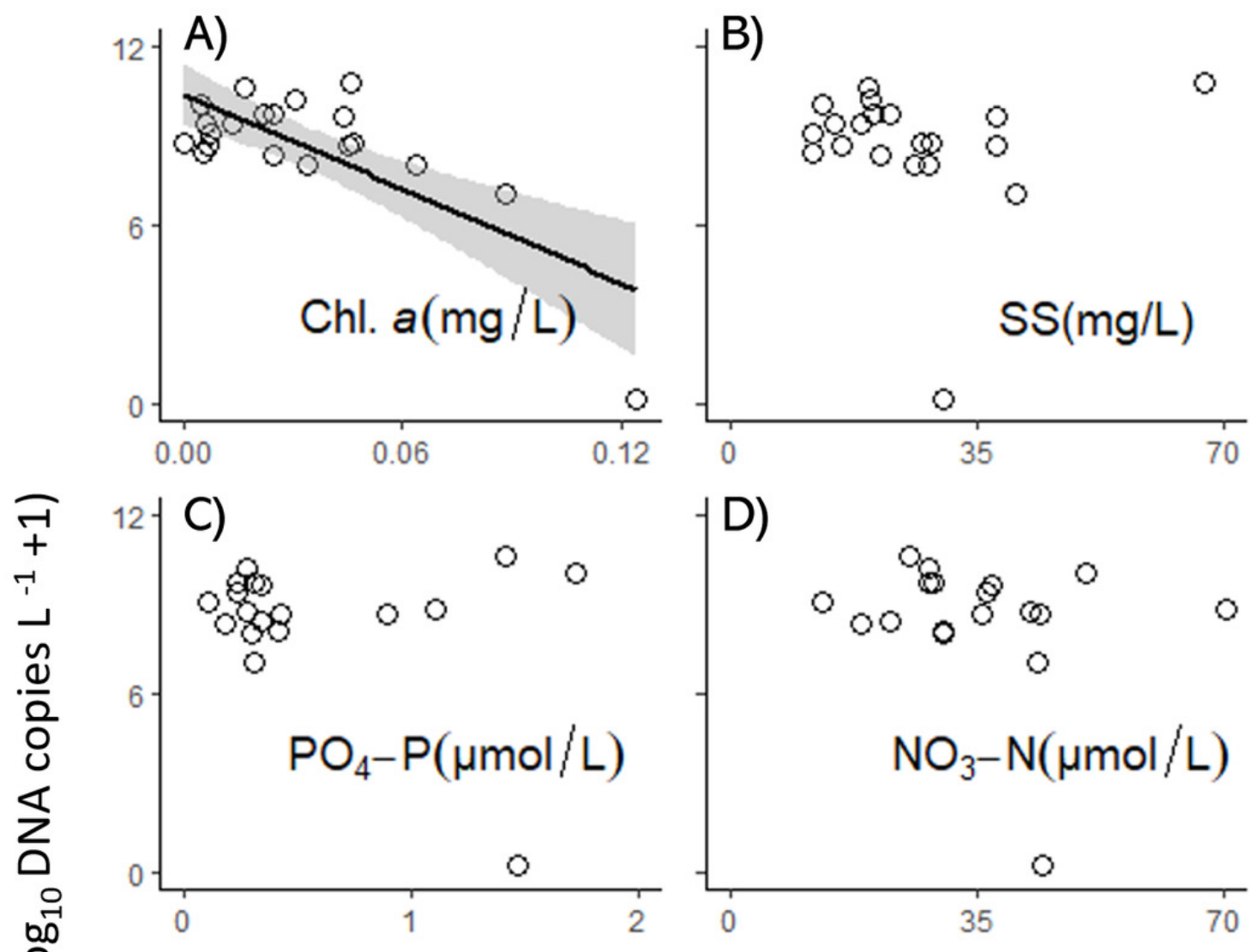

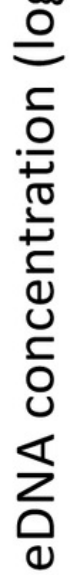
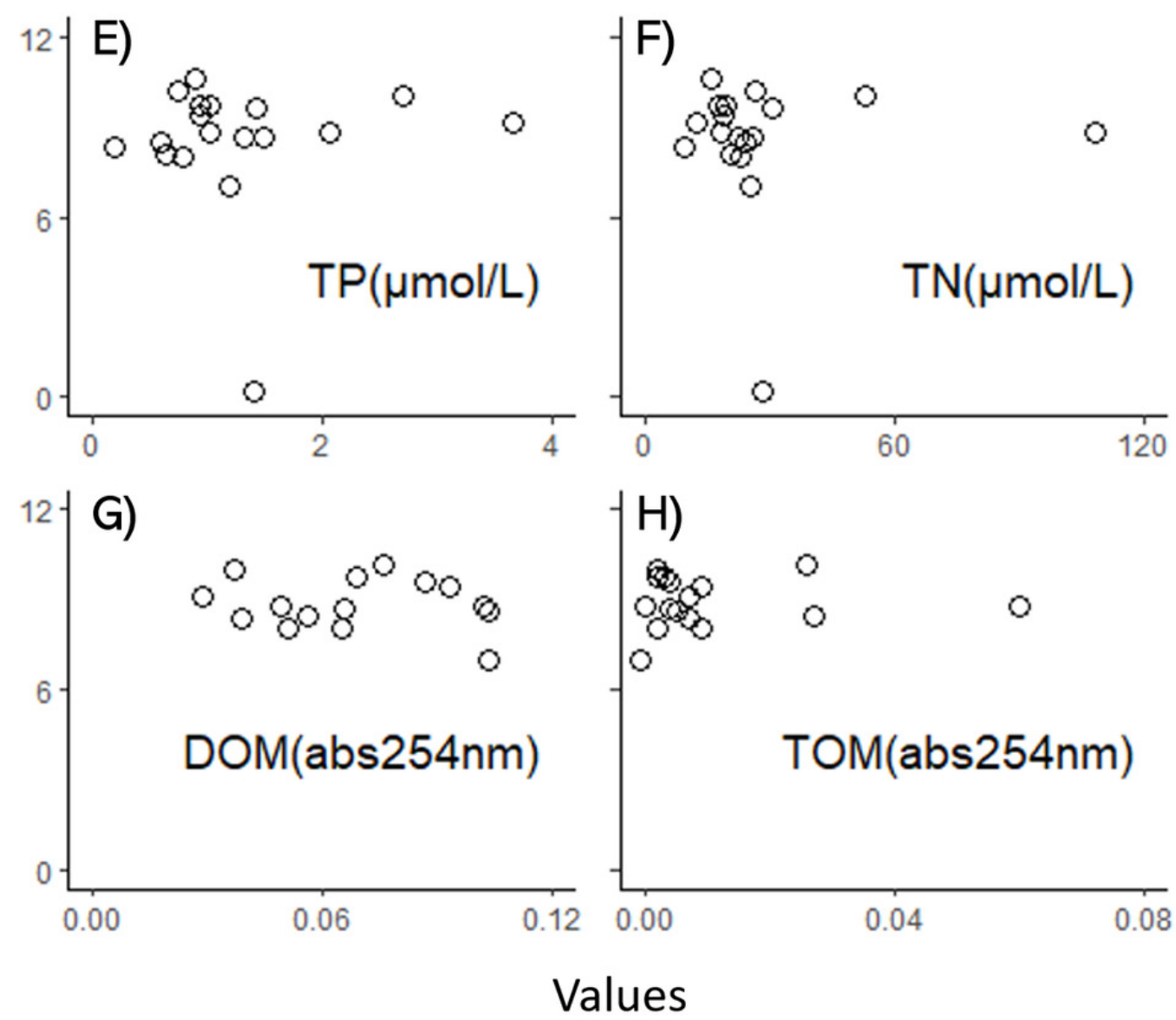


\section{Table 1 (on next page)}

The table represents the $n, F$ value, $p$ value of the $F$ value, $R^{2}$, and adjusted $R^{2}$ for the linear regression. 


\begin{tabular}{lc}
\hline $\mathrm{N}$ & 18 \\
$F$ value & 12.73 \\
$p$ value & 0.000 \\
$R^{2}$ & 0.732 \\
Adjusted $R^{2}$ & 0.674 \\
\hline
\end{tabular}




\section{Table 2 (on next page)}

Table 1 Sampling date, location, the detection ofred-eared slidereDNA, and the number of red-eared slidersvisually observed in the study ponds.

Observed by both eDNA and visual observation is $\odot$. Observed by only eDNA and by only visual observation are $\bigcirc$ and $\bullet$, respectively. 


\begin{tabular}{|c|c|c|c|c|c|}
\hline Pond No. & Date & Latitude & Longtitude & eDNA detected & Visual \\
\hline 1 & $2016 / 7 / 21$ & $34^{\circ} 51^{\prime} 27^{\prime \prime} 71$ & $134^{\circ} 40^{\prime} 36^{\prime \prime} 11$ & (0) & 10 \\
\hline 2 & $2016 / 7 / 29$ & $34^{\circ} 51^{\prime} 15^{\prime \prime} 84$ & $134^{\circ} 41^{\prime} 12^{\prime \prime} 84$ & - & 2 \\
\hline 3 & $2016 / 7 / 29$ & $34^{\circ} 51^{\prime} 16^{\prime \prime} 92$ & $134^{\circ} 41^{\prime} 12^{\prime \prime} 84$ & $\circ$ & - \\
\hline 4 & $2016 / 8 / 4$ & $34^{\circ} 51^{\prime} 02^{\prime \prime} 88$ & $134^{\circ} 41^{\prime} 00^{\prime \prime} 96$ & - & - \\
\hline 5 & $2016 / 8 / 4$ & $34^{\circ} 50^{\prime} 57^{\prime \prime} 12$ & $134^{\circ} 40^{\prime} 46^{\prime \prime} 92$ & (2) & 1 \\
\hline 6 & $2016 / 8 / 8$ & $34^{\circ} 51^{\prime} 36^{\prime \prime} 36$ & $134^{\circ} 40^{\prime} 57^{\prime \prime} 57$ & () & 2 \\
\hline 7 & $2016 / 8 / 8$ & $34^{\circ} 51^{\prime} 30^{\prime \prime} 96$ & $134^{\circ} 40^{\prime} 49^{\prime \prime} 08$ & $\circ$ & - \\
\hline 8 & $2016 / 8 / 10$ & $34^{\circ} 51^{\prime} 02^{\prime \prime} 88$ & $134^{\circ} 40^{\prime} 32^{\prime \prime} 16$ & - & - \\
\hline 9 & $2016 / 8 / 10$ & $34^{\circ} 51^{\prime} 50^{\prime \prime} 27$ & $134^{\circ} 40^{\prime} 36^{\prime \prime} 26$ & - & - \\
\hline 10 & $2016 / 8 / 16$ & $34^{\circ} 51^{\prime} 38^{\prime \prime} 88$ & $134^{\circ} 40^{\prime} 39^{\prime \prime} 39$ & (2) & 10 \\
\hline 11 & $2016 / 8 / 16$ & $34^{\circ} 51^{\prime} 42^{\prime \prime} 12$ & $134^{\circ} 40^{\prime} 27^{\prime \prime} 84$ & $\bullet$ & 1 \\
\hline 12 & $2016 / 8 / 19$ & $34^{\circ} 50^{\prime} 24^{\prime \prime} 24$ & $134^{\circ} 41^{\prime} 42^{\prime \prime} 42$ & - & - \\
\hline 13 & $2016 / 8 / 19$ & $34^{\circ} 50^{\prime} 26^{\prime \prime} 88$ & $134^{\circ} 41^{\prime} 30^{\prime \prime} 84$ & (2) & 3 \\
\hline 14 & $2016 / 8 / 26$ & $34^{\circ} 51^{\prime} 52^{\prime \prime} 92$ & $134^{\circ} 40^{\prime} 35^{\prime \prime} 04$ & () & 1 \\
\hline 15 & $2016 / 10 / 7$ & $34^{\circ} 52^{\prime} 15^{\prime \prime} 97$ & $134^{\circ} 41^{\prime} 11^{\prime \prime} 45$ & - & - \\
\hline 16 & $2016 / 10 / 7$ & $34^{\circ} 52^{\prime 2} 21^{\prime \prime} 91$ & $134^{\circ} 41^{\prime} 10^{\prime \prime} 54$ & (0) & 1 \\
\hline 17 & $2016 / 10 / 7$ & $34^{\circ} 52^{\prime} 19^{\prime \prime} 39$ & $134^{\circ} 41^{\prime} 12^{\prime \prime} 48$ & - & - \\
\hline 18 & $2016 / 10 / 7$ & $34^{\circ} 52^{\prime} 24^{\prime \prime} 05$ & $134^{\circ} 41^{\prime} 10^{\prime \prime 2} 23$ & - & - \\
\hline 19 & $2016 / 10 / 7$ & $34^{\circ} 52^{\prime} 06^{\prime \prime} 21$ & $134^{\circ} 41^{\prime} 48^{\prime \prime} 00$ & - & 1 \\
\hline 20 & $2016 / 10 / 7$ & $34^{\circ} 52^{\prime} 02^{\prime \prime} 02$ & $134^{\circ} 41^{\prime} 48^{\prime \prime} 27$ & $\circ$ & - \\
\hline 21 & $2016 / 10 / 14$ & $34^{\circ} 51^{\prime} 36^{\prime \prime} 40$ & $134^{\circ} 42^{\prime} 38^{\prime \prime} 65$ & - & - \\
\hline 22 & $2016 / 10 / 14$ & $34^{\circ} 51^{\prime} 52^{\prime \prime} 94$ & $134^{\circ} 42^{\prime} 04^{\prime \prime} 27$ & - & - \\
\hline 23 & $2016 / 10 / 14$ & $34^{\circ} 51^{\prime} 47^{\prime \prime} 99$ & $134^{\circ} 42^{\prime} 14^{\prime \prime} 86$ & 0 & - \\
\hline 24 & $2016 / 10 / 14$ & $34^{\circ} 51^{\prime} 44^{\prime \prime} 67$ & $134^{\circ} 42^{\prime} 14^{\prime \prime} 22$ & - & - \\
\hline 25 & $2016 / 10 / 14$ & $34^{\circ} 51^{\prime} 42^{\prime \prime} 18$ & $134^{\circ} 41^{\prime} 59^{\prime \prime} 00$ & - & - \\
\hline 26 & $2016 / 10 / 14$ & $34^{\circ} 51^{\prime} 44^{\prime \prime} 11$ & $134^{\circ} 41^{\prime} 52^{\prime \prime} 91$ & - & - \\
\hline 27 & $2016 / 10 / 14$ & $34^{\circ} 51^{\prime} 40^{\prime \prime} 18$ & $134^{\circ} 41^{\prime} 22^{\prime \prime} 60$ & - & - \\
\hline 28 & $2016 / 10 / 14$ & $34^{\circ} 51^{\prime} 38^{\prime \prime} 16$ & $134^{\circ} 41^{\prime} 17^{\prime \prime} 16$ & $\bullet$ & 1 \\
\hline 29 & $2016 / 10 / 14$ & $34^{\circ} 51^{\prime} 50^{\prime \prime} 62$ & $134^{\circ} 40^{\prime} 57^{\prime \prime} 02$ & - & - \\
\hline 30 & $2016 / 10 / 14$ & $34^{\circ} 51^{\prime} 48^{\prime \prime} 96$ & $134^{\circ} 40^{\prime} 56^{\prime \prime} 23$ & $\bullet$ & 3 \\
\hline 31 & $2016 / 10 / 17$ & $34^{\circ} 51^{\prime} 54^{\prime \prime} 45$ & $134^{\circ} 40^{\prime} 37^{\prime \prime} 75$ & - & - \\
\hline 32 & $2016 / 10 / 17$ & $34^{\circ} 51^{\prime} 57^{\prime \prime} 51$ & $134^{\circ} 40^{\prime} 28^{\prime \prime} 63$ & - & - \\
\hline 33 & $2016 / 10 / 17$ & $34^{\circ} 51^{\prime} 52^{\prime \prime} 84$ & $134^{\circ} 40^{\prime} 48^{\prime \prime} 37$ & - & - \\
\hline 34 & $2016 / 10 / 19$ & $34^{\circ} 51^{\prime} 43^{\prime \prime} 21$ & $134^{\circ} 35^{\prime} 35^{\prime \prime} 21$ & $\circ$ & - \\
\hline 35 & $2016 / 10 / 19$ & $34^{\circ} 51^{\prime} 43^{\prime \prime} 34$ & $134^{\circ} 35^{\prime} 26^{\prime \prime} 03$ & - & 1 \\
\hline 36 & $2016 / 10 / 19$ & $34^{\circ} 51^{\prime} 46^{\prime \prime} 64$ & $134^{\circ} 35^{\prime} 17^{\prime \prime} 99$ & - & - \\
\hline 37 & $2016 / 10 / 19$ & $34^{\circ} 51^{\prime} 41^{\prime \prime} 91$ & $134^{\circ} 35^{\prime} 46^{\prime \prime} 99$ & - & - \\
\hline 38 & 2016/10/19 & $34^{\circ} 51^{\prime} 53^{\prime \prime} 15$ & $134^{\circ} 35^{\prime} 51^{\prime \prime} 31$ & - & - \\
\hline 39 & $2016 / 10 / 19$ & $34^{\circ} 52^{\prime} 06^{\prime \prime} 27$ & $134^{\circ} 35^{\prime} 47^{\prime \prime} 93$ & - & - \\
\hline 40 & $2016 / 10 / 19$ & $34^{\circ} 52^{\prime} 16^{\prime \prime} 58$ & $134^{\circ} 35^{\prime} 44^{\prime \prime} 54$ & - & - \\
\hline 41 & $2016 / 10 / 19$ & $34^{\circ} 51^{\prime} 31^{\prime \prime} 47$ & $134^{\circ} 35^{\prime} 53^{\prime \prime} 56$ & (2) & 4 \\
\hline 42 & $2016 / 10 / 19$ & $34^{\circ} 51^{\prime} 32^{\prime \prime} 04$ & $134^{\circ} 36^{\prime} 02^{\prime \prime} 88$ & () & 1 \\
\hline 43 & $2016 / 10 / 19$ & $34^{\circ} 51^{\prime} 28^{\prime \prime} 49$ & $134^{\circ} 36^{\prime} 06^{\prime \prime} 63$ & $\bullet$ & 5 \\
\hline 44 & $2016 / 10 / 19$ & $34^{\circ} 51^{\prime} 27^{\prime \prime} 27$ & $134^{\circ} 36^{\prime} 02^{\prime \prime} 16$ & - & - \\
\hline 45 & $2016 / 10 / 19$ & $34^{\circ} 51^{\prime} 29^{\prime \prime} 60$ & $134^{\circ} 35^{\prime} 20^{\prime \prime} 10$ & - & - \\
\hline 46 & $2016 / 10 / 19$ & $34^{\circ} 51^{\prime} 33^{\prime \prime} 48$ & $134^{\circ} 35^{\prime} 25^{\prime \prime} 09$ & 0 & - \\
\hline 47 & $2016 / 10 / 19$ & $34^{\circ} 51^{\prime} 40^{\prime \prime} 47$ & $134^{\circ} 35^{\prime} 24^{\prime \prime} 34$ & - & - \\
\hline 48 & $2016 / 10 / 21$ & $34^{\circ} 51^{\prime} 55^{\prime \prime} 82$ & $134^{\circ} 36^{\prime} 13^{\prime \prime} 86$ & - & - \\
\hline 49 & $2016 / 10 / 21$ & $34^{\circ} 52^{\prime} 00^{\prime \prime} 86$ & $134^{\circ} 36^{\prime} 09^{\prime \prime} 34$ & - & - \\
\hline 50 & $2016 / 10 / 21$ & $34^{\circ} 52^{\prime} 19^{\prime \prime} 20$ & $134^{\circ} 36^{\prime} 07^{\prime \prime 22}$ & - & - \\
\hline
\end{tabular}


$2 \mathrm{~B})$

\begin{tabular}{|c|c|c|c|c|c|}
\hline Pond No. & Date & Latitude & Longtitude & eDNA detected & Visual \\
\hline 51 & $2016 / 10 / 21$ & $34^{\circ} 52^{\prime} 18^{\prime \prime} 12$ & $134^{\circ} 36^{\prime} 11^{\prime \prime} 16$ & $\bullet$ & 3 \\
\hline 52 & $2016 / 10 / 21$ & $34^{\circ} 52^{\prime} 14^{\prime \prime} 80$ & $134^{\circ} 36^{\prime} 20^{\prime \prime} 07$ & - & - \\
\hline 53 & $2016 / 10 / 21$ & $34^{\circ} 52^{\prime} 36^{\prime \prime} 15$ & $134^{\circ} 36^{\prime} 52^{\prime \prime} 11$ & - & - \\
\hline 54 & $2016 / 10 / 21$ & $34^{\circ} 52^{\prime} 23^{\prime \prime} 71$ & $134^{\circ} 36^{\prime} 55^{\prime \prime} 38$ & - & - \\
\hline 55 & $2016 / 10 / 21$ & $34^{\circ} 52^{\prime} 08^{\prime \prime} 35$ & $134^{\circ} 37^{\prime} 21^{\prime \prime} 82$ & - & - \\
\hline 56 & $2016 / 10 / 26$ & $34^{\circ} 48^{\prime} 49^{\prime \prime} 62$ & $134^{\circ} 45^{\prime} 28^{\prime \prime} 46$ & - & - \\
\hline 57 & $2016 / 10 / 26$ & $34^{\circ} 48^{\prime} 45^{\prime \prime} 99$ & $134^{\circ} 45^{\prime} 20^{\prime \prime} 11$ & - & - \\
\hline 58 & $2016 / 10 / 26$ & $34^{\circ} 49^{\prime} 02^{\prime \prime} 53$ & $134^{\circ} 45^{\prime} 17^{\prime \prime} 81$ & - & - \\
\hline 59 & $2016 / 10 / 26$ & $34^{\circ} 49^{\prime} 17^{\prime \prime} 61$ & $134^{\circ} 45^{\prime} 17^{\prime \prime} 76$ & - & - \\
\hline 60 & $2016 / 10 / 26$ & $34^{\circ} 49^{\prime} 11^{\prime \prime} 13$ & $134^{\circ} 45^{\prime} 09^{\prime \prime} 65$ & $\circ$ & - \\
\hline 61 & $2016 / 10 / 26$ & $34^{\circ} 49^{\prime} 09^{\prime \prime} 75$ & $134^{\circ} 45^{\prime} 04^{\prime \prime} 08$ & $\circ$ & - \\
\hline 62 & $2016 / 10 / 26$ & $34^{\circ} 47^{\prime} 55^{\prime \prime} 70$ & $134^{\circ} 44^{\prime} 30^{\prime \prime} 60$ & - & - \\
\hline 63 & $2016 / 10 / 26$ & $34^{\circ} 47^{\prime} 51^{\prime \prime} 66$ & $134^{\circ} 44^{\prime} 32^{\prime \prime} 38$ & - & - \\
\hline 64 & $2016 / 10 / 26$ & $34^{\circ} 47^{\prime} 49^{\prime \prime} 32$ & $134^{\circ} 44^{\prime} 27^{\prime \prime} 66$ & - & - \\
\hline 65 & $2016 / 10 / 26$ & $34^{\circ} 47^{\prime} 44^{\prime \prime} 73$ & $134^{\circ} 44^{\prime} 28^{\prime \prime} 25$ & - & - \\
\hline 66 & $2016 / 10 / 26$ & $34^{\circ} 47^{\prime} 27^{\prime \prime} 68$ & $134^{\circ} 44^{\prime} 28^{\prime \prime} 04$ & - & - \\
\hline 67 & $2016 / 10 / 26$ & $34^{\circ} 47^{\prime} 26^{\prime \prime} 17$ & $134^{\circ} 44^{\prime} 30^{\prime \prime} 00$ & - & - \\
\hline 68 & $2016 / 10 / 26$ & $34^{\circ} 47^{\prime} 41^{\prime \prime} 37$ & $134^{\circ} 44^{\prime} 34^{\prime \prime} 11$ & - & - \\
\hline 69 & $2016 / 10 / 26$ & $34^{\circ} 47^{\prime} 44^{\prime \prime} 19$ & $134^{\circ} 44^{\prime} 39^{\prime \prime} 70$ & - & - \\
\hline 70 & $2016 / 11 / 2$ & $34^{\circ} 52^{\prime} 04^{\prime \prime} 71$ & $134^{\circ} 41^{\prime} 09^{\prime \prime} 82$ & $\circ$ & - \\
\hline 71 & $2016 / 11 / 2$ & $34^{\circ} 52^{\prime} 08^{\prime \prime} 04$ & $134^{\circ} 40^{\prime} 33^{\prime \prime} 96$ & (2) & 40 \\
\hline 72 & $2016 / 11 / 2$ & $34^{\circ} 52^{\prime} 08^{\prime \prime} 77$ & $134^{\circ} 40^{\prime} 32^{\prime \prime} 74$ & (2) & 10 \\
\hline 73 & $2016 / 11 / 2$ & $34^{\circ} 52^{\prime} 17^{\prime \prime} 98$ & $134^{\circ} 40^{\prime} 33^{\prime \prime} 59$ & $\bullet$ & 1 \\
\hline 74 & $2016 / 11 / 2$ & $34^{\circ} 52^{\prime} 20^{\prime \prime} 97$ & $134^{\circ} 40^{\prime} 12^{\prime \prime} 81$ & - & - \\
\hline 75 & $2016 / 11 / 10$ & $34^{\circ} 52^{\prime} 44^{\prime \prime} 93$ & $134^{\circ} 36^{\prime} 26^{\prime \prime} 46$ & - & - \\
\hline 76 & $2016 / 11 / 10$ & $34^{\circ} 53^{\prime} 04^{\prime \prime} 92$ & $134^{\circ} 36^{\prime} 56^{\prime \prime} 88$ & - & - \\
\hline 77 & $2016 / 11 / 10$ & $34^{\circ} 53^{\prime} 06^{\prime \prime} 74$ & $134^{\circ} 37^{\prime} 01^{\prime \prime 2} 27$ & - & - \\
\hline 78 & $2016 / 11 / 10$ & $34^{\circ} 53^{\prime} 22^{\prime \prime} 42$ & $134^{\circ} 36^{\prime} 02^{\prime \prime} 79$ & - & - \\
\hline 79 & $2016 / 11 / 10$ & $34^{\circ} 53^{\prime} 22^{\prime \prime} 97$ & $134^{\circ} 35^{\prime} 58^{\prime \prime} 44$ & - & - \\
\hline 80 & $2016 / 11 / 10$ & $34^{\circ} 53^{\prime} 30^{\prime \prime} 58$ & $134^{\circ} 36^{\prime} 29^{\prime \prime} 18$ & - & - \\
\hline 81 & $2016 / 11 / 10$ & $34^{\circ} 53^{\prime} 33^{\prime \prime} 12$ & $134^{\circ} 36^{\prime} 30^{\prime \prime} 51$ & - & - \\
\hline 82 & $2016 / 11 / 10$ & $34^{\circ} 53^{\prime} 32^{\prime \prime} 29$ & $134^{\circ} 36^{\prime} 34^{\prime \prime} 27$ & - & - \\
\hline 83 & $2016 / 11 / 10$ & $34^{\circ} 54^{\prime} 00^{\prime \prime} 96$ & $134^{\circ} 36^{\prime} 15^{\prime \prime} 60$ & - & - \\
\hline 84 & $2016 / 11 / 10$ & $34^{\circ} 53^{\prime} 51^{\prime \prime} 23$ & $134^{\circ} 36^{\prime} 06^{\prime \prime} 41$ & - & - \\
\hline 85 & $2016 / 11 / 16$ & $34^{\circ} 53^{\prime} 58^{\prime \prime} 77$ & $134^{\circ} 36^{\prime} 39^{\prime \prime} 56$ & - & - \\
\hline 86 & $2016 / 11 / 16$ & $34^{\circ} 53^{\prime} 59^{\prime \prime} 25$ & $134^{\circ} 36^{\prime} 36^{\prime \prime} 64$ & - & - \\
\hline 87 & $2016 / 11 / 16$ & $34^{\circ} 54^{\prime} 09^{\prime \prime} 90$ & $134^{\circ} 36^{\prime} 33^{\prime \prime} 84$ & - & - \\
\hline 88 & $2016 / 11 / 16$ & $34^{\circ} 54^{\prime} 07^{\prime \prime} 92$ & $134^{\circ} 36^{\prime} 33^{\prime \prime} 12$ & - & - \\
\hline 89 & $2016 / 11 / 16$ & $34^{\circ} 54^{\prime} 13^{\prime \prime} 64$ & $134^{\circ} 36^{\prime} 05^{\prime \prime} 48$ & - & - \\
\hline 90 & $2016 / 11 / 16$ & $34^{\circ} 54^{\prime} 19^{\prime \prime} 24$ & $134^{\circ} 35^{\prime} 45^{\prime \prime} 65$ & - & - \\
\hline 91 & $2016 / 11 / 16$ & $34^{\circ} 54^{\prime} 17^{\prime \prime} 99$ & $134^{\circ} 35^{\prime} 40^{\prime \prime} 68$ & - & - \\
\hline 92 & $2016 / 11 / 16$ & $34^{\circ} 54^{\prime} 09^{\prime \prime} 87$ & $134^{\circ} 35^{\prime} 46^{\prime \prime} 19$ & - & - \\
\hline 93 & $2016 / 11 / 16$ & $34^{\circ} 54^{\prime} 06^{\prime \prime} 24$ & $134^{\circ} 35^{\prime} 39^{\prime \prime} 84$ & - & - \\
\hline 94 & $2016 / 11 / 16$ & $34^{\circ} 54^{\prime} 30^{\prime \prime} 99$ & $134^{\circ} 35^{\prime} 33^{\prime \prime} 98$ & - & - \\
\hline 95 & $2016 / 11 / 16$ & $34^{\circ} 54^{\prime} 30^{\prime \prime} 37$ & $134^{\circ} 35^{\prime} 41^{\prime \prime} 57$ & - & - \\
\hline 96 & $2016 / 11 / 16$ & $34^{\circ} 54^{\prime} 36^{\prime \prime} 81$ & $134^{\circ} 35^{\prime} 39^{\prime \prime} 32$ & - & - \\
\hline 97 & $2016 / 11 / 16$ & $34^{\circ} 54^{\prime} 30^{\prime \prime} 37$ & $134^{\circ} 35^{\prime} 47^{\prime \prime} 51$ & - & - \\
\hline 98 & $2016 / 11 / 16$ & $34^{\circ} 54^{\prime} 41^{\prime \prime} 97$ & $134^{\circ} 35^{\prime} 47^{\prime \prime} 75$ & $\bullet$ & 1 \\
\hline 99 & $2016 / 11 / 16$ & $34^{\circ} 54^{\prime} 56^{\prime \prime} 00$ & $134^{\circ} 36^{\prime} 00^{\prime \prime} 70$ & - & - \\
\hline 100 & $2016 / 11 / 16$ & $34^{\circ} 54^{\prime} 57^{\prime \prime} 30$ & $134^{\circ} 36^{\prime} 06^{\prime \prime} 47$ & - & - \\
\hline
\end{tabular}




\section{Table 3 (on next page)}

Table 2 a) Linear regression slopes with a $\pm 95 \%$ confidence interval, SE, t values, and $p$ values for the relationships between Chl. $a, \mathrm{TP}$, and eDNA concentrations in the ponds.

Factors with a VIF $>5$ were removed. 
A)

2

3

4

5

6

7

8

9

10

11

12

13

14

15

16

\begin{tabular}{lcccc}
\hline \multicolumn{1}{c}{ factors } & slope & SE & $t$ value & $p$ value \\
\hline Chl. $a$ & -48.550 & 10.740 & -4.519 & 0.000 \\
TP & -0.345 & 0.392 & -0.882 & 0.393 \\
Turtles & 0.000 & 0.000 & 2.075 & 0.057 \\
Intercept & 10.450 & 0.754 & 13.865 & 0.000 \\
\hline
\end{tabular}

B)

\begin{tabular}{lc}
\hline $\mathrm{N}$ & 18 \\
$F$ value & 12.73 \\
$p$ value & 0.000 \\
$R^{2}$ & 0.732 \\
Adjusted $R^{2}$ & 0.674 \\
\hline
\end{tabular}

